\title{
Nordic
}

\section{STUDIES IN EDUCATION}

Article | Peer-reviewed | Vol. 41, No. 3, 2021, pp. 219-238

\section{"We Want to Be Educated!" A Thematic Analysis of Gifted Students' Views on Education in Norway}

\section{Astrid Lenvik}

Department of Education, University of Bergen, Norway

Contact corresponding author: Astrid.Lenvik@uib.no

\section{Elisabeth Hesjedal}

Department of Education, University of Bergen, Norway

\section{Lise Øen Jones}

Department of Psychosocial Science, University of Bergen, Norway

\begin{abstract}
Norwegian educational policy focuses on inclusive, equivalent, and adapted education for all. We followed procedures for an inductive thematic approach to explore the educational experiences of seventeen gifted students (age twelve - fifteen). The inductive thematic analysis revealed three key themes: the educational system, the joy of learning, and problematic issues concerning school and learning. Our results are discussed in light of educational policy and Gagné's Differentiated Model of Giftedness and Talent, and indicate that the Norwegian educational system does not meet these gifted students' needs at either the individual or systemic levels. This study is vital for gaining a better understanding of the Norwegian perspective as well as the wider Nordic setting.
\end{abstract}

Keywords: gifted education, primary school, secondary school, inductive thematic analysis, educational policy

Being a gifted student in a heterogeneous class is not necessarily an easy task. International research has shown that gifted students who are not part of a gifted program may develop issues related to behavior, drop out of school, or just give up on education and school altogether (J. R. Cross \& T. L. Cross, 2015; T. L. Cross et al., 2014; Subotnik et al.,

Manuscript received: 30.09.2020. Manuscript accepted: 08.02.2021.

(C) 2021 A. Lenvik, E. Hesjedal \& L. Ø. Jones. This is an Open Access article distributed under the terms of the Creative Commons CC-BY 4.0 License. ISSN 1891-5949, https://noredstudies.org

Citation: Lenvik, A., Hesjedal, E. \& Jones, L. Ø. (2021). "We want to be educated!" A thematic analysis of gifted students' views on education in Norway. Nordic Studies in Education, 41(3), 219-238. https://doi.org/10.23865/ nse.v41.2621 
2011). Gifted students report feelings of otherness from their peers, apathy for school, that school is an obligation or "prison," a need for sufficient challenges and differentiation, and the importance of their teacher (Borovay et al., 2019; Brandišauskienè, 2019; Gomez-Arizaga et al., 2020; McGrath, 2019; Samardzija \& Peterson, 2015; Smith \& Goebel, 2015; Yavuz et al., 2016). This inductive qualitative study aims to explore the educational experiences of seventeen gifted students in Norwegian secondary schools. The gifted students report on their secondary school education and retrospectively on their primary school education.

\section{Educational provisions for gifted students}

There are three primary educational provisions for gifted students: segregation, acceleration, and inclusion (Rasmussen \& Lingard, 2018). Segregation and acceleration involve identifying gifted students and providing for them in segregated or accelerated classes. Acceleration can also entail skipping grades or entering comprehensive school earlier than peers.

Acceleration is often viewed as harmful to the students' psychological and social well-being, both by teachers and parents (Bernstein et al., 2020; Dare \& Nowicki, 2019; Steenbergen-Hu et al., 2016). However, a longitudinal study of educational acceleration concluded that acceleration did not negatively affect psychological well-being (Bernstein et al., 2020). Gifted students benefit from grouping within the class, across grades in particular subjects, and by unique grouping for gifted students (Steenbergen-Hu et al., 2016). Acceleration has a positive, moderate, and significant impact on student academic achievement, and accelerated students outperform their non-accelerated same-age peers (Steenbergen-Hu et al., 2016).

Inclusive provisions for gifted students are approaches within the same-age classroom involving differentiation and enrichment strategies (Rasmussen \& Lingard, 2018; VanTassel-Baska \& Hubbard, 2016). Differentiation may involve the inclusion of advanced content from higher grade levels, critical thinking and problem-solving skills, projects and problem-based learning (Betts, 2004; VanTassel-Baska \& Hubbard, 2016). Gifted students prefer more demanding work and accelerated subjects with older students, and enrichment activities that are active, inquisitive, open-ended, and varied, as well as tailored to different learning styles (Borovay et al., 2019; Gomez-Arizaga et al., 2020; McGrath, 2019; Samardzija \& Peterson, 2015).

Teachers may have negative attitudes towards giftedness and gifted education; including, for example, the idea that gifted students do not need educational provisions, or that the acceleration or segregation of gifted students is harmful. If teachers have knowledge and training about giftedness and gifted education, they are more likely to meet gifted students' educational needs (Geake \& Gross, 2008). Students prefer engaging, professional, and competent teachers who have reasonable control in their classroom (Samardzija \& Peterson, 2015; Smith \& Goebel, 2015). 


\section{Nordic research on gifted education}

According to several comparison studies, there is not much information to be found about gifted education in the Nordic countries (Frantz \& McClarty, 2016; Mönks \& Pflüger, 2005; Reid \& Boettger, 2015).

Finland has a highly developed educational system, which educates all children according to their individual needs. However, some Finnish teachers have a fixed ability mindset, and teachers need more knowledge about giftedness's socialemotional aspects (Tirri \& Kuusisto, 2013). There are opportunities for acceleration through earlier entry to comprehensive school and enrichment and extra-curricular activities like summer camps or talent classes in Finland, Denmark, and Sweden (Dodillet, 2019; Rasmussen \& Lingard, 2018; Tirri \& Kuusisto, 2013). Gifted Swedish adults regard their education as unsatisfactory, with primary school being the least satisfying (Persson, 2010).

Wendelborg and Caspersen (2016) found that high achievers in Norway report less teacher support, not enough challenges, lack of relevance, and a higher degree of bullying (Wendelborg \& Caspersen, 2016). Smedsrud (2018) found in his interview study of eleven Norwegian accelerated math students that they did not receive sufficient challenges, especially in early primary school.

\section{Gifted education in Norway}

Norway bases its educational system on equity, inclusion, and adaption to the different abilities and aptitudes of students; an ideology based on the UN Convention on the Rights of the Child and the Salamanca Statement (Ministry of Children and Families, 1991; The Education Act, 1998, § 1-1, § 1-3; UNESCO, 1994). Norwegian students also have the right to be involved in and influence their education (The Education Act, 1998). If ordinary education does not cover students' needs, they should receive special education (The Education Act, 1998, § 5-1). Adapted education covers both ordinary education and special education (Nordahl et al., 2018).

In 2016, an official investigation concluded that three main systematic realizations were needed to better provide for students with high learning potential (gifted) (NOU 2016: 14, 2016). Primary and secondary education is not adapted enough to realize gifted students' learning potential. Schools are not utilizing the possibilities for pedagogical and organizational differentiation. The educational system needs a joint knowledge base (NOU 2016: 14, 2016, p. 8).

Gifted education can be a part of special education, and receive special education stature (Mönks \& Pflüger, 2005; Parliamentary Assembly Council of Europe, 1994). However, Norway reserves special education for students with, e.g., learning difficulties, and the Norwegian Directorate of Education and Training (NDET) concludes that students with high learning potential have a satisfactory yield within ordinary adapted education (NDET, 2014). Adapted education covers ordinary and special education; in special education, adaptation is considered an individual right, while adaptation in 
ordinary education is supposed to be achieved through variation and modification according to students' diverse needs (NDET, 2020).

Educational provisions for gifted students in Norway include acceleration through early entry to comprehensive school and skipping grades later, and single subject acceleration (NOU 2016:14, 2016). Teachers can use enrichment strategies through adapted education and differentiation, but we have little knowledge about the enrichment and differentiation these students get in Norway (Børte et al., 2016).

\section{Theories on giftedness and development}

There are several definitions and theories regarding giftedness and development. In this article, we will refer to three different theories: the three-ring conception of giftedness (Renzulli, 2012), the Multifactor Model of Giftedness (MMG) (Mönks \& Katzko, 2005), and the Differentiated Model of Giftedness and Talent (DMGT) (Gagné, 1995, 2004, 2010).

The three-ring conception of giftedness model displays three interactive clusters: above-average ability, task commitment, and creativity (Renzulli, 2012). These traits represent the main dimensions for creative productivity, and it is the interaction between these traits that creates fruitful conditions for a creative, productive process (Renzulli, 2012). Above average ability can be both general intellectual ability and a specific ability like, e.g., music. Task commitment is a focused or refined form of motivation, and creativity includes traits like curiosity, originality, and a willingness to challenge convention and tradition (Renzulli, 2012). The Multifactor Model of Giftedness combines these traits with support from the main environmental components: peers, family, and school (Mönks \& Katzko, 2005). The MMG emphasizes that giftedness can only develop in a fruitful interaction with the environmental dimension.

According to Gagné (2010), giftedness is the possession of natural abilities or aptitudes that are untrained, spontaneously expressed, and considered outstanding. In Gagné's (2010) model, he emphasizes three catalysts, the intrapersonal, the environment, and chance. Through a developmental process, the natural abilities (gifts) develop into a systematically developed skill (talent). The catalysts will influence the developmental process and might promote or hinder development. The intrapersonal catalyst includes traits like physical characteristics, motivation, and personality. The environmental catalyst represents the milieu or environment with significant persons, provisions, and significant events (Gagné, 2004, 2010). Chance influences both the intrapersonal catalyst, the environmental catalyst, and the developmental process itself. While it is possible to reduce some amount of chance, for example through the provision of a high standard of education for all students in all regions of a country, there will still be elements of chance that influence a child's development.

\section{Current study}

In this study, we aim to explore gifted education in Norway. The main research question is, "How do Norwegian gifted secondary school students experience their education?" 
There are few studies on gifted education in Norway, and it is crucial to explore this phenomenon from the perspective of those experiencing it. How do gifted students experience the educational provisions they get? Are their experiences different between primary and secondary school? How do these students relate to their teachers, and what kind of teachers do these students prefer?

This study will focus on the environmental catalyst in the DMGT, the environmental dimensions in the MMG, and the intellectual domain, which is the most familiar domain attributed to giftedness (Subotnik et al., 2011).

\section{Method}

This article draws on a qualitative study (Braun \& Clarke, 2006) with data from personal (face to face) semi-structured interviews (Brinkmann, 2015) with seventeen gifted students in Norwegian secondary schools, conducted by the first author during the spring of 2018. The inductive thematic analysis was driven by the data content, with the research question as a guide (Braun et al., 2015). The interview duration ranged from sixteen minutes to one hour and twenty minutes. The total amount of data consists of 303 pages of transcript (Times New Roman, size 12, line spacing 1.5).

\section{Interview Guide}

We developed the semi-structured interview guide from the research question "How do Norwegian gifted secondary school students experience school?" as well as previous research in the field (Kvale \& Brinkmann, 2015). We also did a quantitative survey with teachers before the interviews, which yielded some topics like facilitation and teachers' recognition of talent. We did a pilot interview before the data collection, which prompted some changes in wording. The main topics were experiences and strategies in school, adapted education, family and friends, underachievement, social-emotional issues, and involvement in their education.

\section{The informants}

Participants in this study are seventeen students between twelve and fifteen years (mean age fourteen) attending secondary school in Norway. Eleven participants are male, and six are female. The selection is a convenience sample (Gorard, 2001). There is an overweight of one gender, but we have not considered gender differences in this study.

We recruited the informants in the study by contacting "Happy Children," a network for parents of gifted kids in Norway. We utilized social media, contacted all secondary schools in our home municipality, and reached out to a talent center in Math and Science. Inclusion criteria in this study was nomination by a teacher or parent, and a score of $95^{\text {th }}$ percentile or above on at least one subscale in WISC-IV, Verbal Comprehension (VC), Perceptual Reasoning (PR), Working Memory (WM), or Processing Speed (PS). The first author tested thirteen of the participants; the remaining four had 
been tested previously. The informants in this study are gifted more specifically in the $\mathrm{VC}$, which means that they are exceptionally talented in language, reading, writing, or PR, which means they have talents with logical fluid reasoning and visual-spatial skills. Some had a homogenous profile with high scores in all domains, while others scored substantially better on VC or PR.

\section{Analysis}

Thematic analysis is a common analytical method in qualitative interview studies (Braun et al., 2019; Braun et al., 2015; Braun \& Clarke, 2006). We followed the six steps listed by Braun and Clarke (2006) for inductive thematic analysis. The first step was a close reading of the transcripts. The first author transcribed all of the interviews, and all authors read the transcripts. Step two is generating initial codes. See table 1 for an example of the preliminary coding.

Table 1: Coding example

\begin{tabular}{|c|c|c|}
\hline TEXT & CODE(S) & NOTE \\
\hline $\begin{array}{l}\text { Well it was an assignement where I was suppo- } \\
\text { sed to write about a book we had been reading } \\
\text { in class, that was interesting. So I just started } \\
\text { working, and working and I thought it was nice } \\
\text { to write and feel like I'm coping with the assign- } \\
\text { ment. That's a very nice feeling. }\end{array}$ & $\begin{array}{l}\text { Academic self- } \\
\text { confidence }\end{array}$ & $\begin{array}{l}\text { Positive feeling of } \\
\text { coping, interesting and } \\
\text { challenging assignments. }\end{array}$ \\
\hline $\begin{array}{l}\text { [ehm] I was kinda put in a class where I was like } \\
\text { the "smart one", because "wow she reads books } \\
\text { in recess. And she pays attention in class!" And I } \\
\text { always thought it was strange, so I kinda just got } \\
\text { that role, like that. }\end{array}$ & $\begin{array}{l}\text { Primary school, } \\
\text { Comments from } \\
\text { other students, } \\
\text { Roles }\end{array}$ & $\begin{array}{l}\text { Didn't feel like they fit } \\
\text { in the class, they got a } \\
\text { role as «the smart one» } \\
\text { because of reading books } \\
\text { and paying attention. }\end{array}$ \\
\hline $\begin{array}{l}\text { I like it best in secondary school. But I think it } \\
\text { has a lot to do with the environment also. And, } \\
\text { yeah I got involved in the wrong crowd like... } \\
\text { and I think the subjects are more fun, and like } \\
\text { there is more discussion and not just what the } \\
\text { book says and remember that to the test. Like } \\
\text { there is much more discussions in class, and we } \\
\text { try to reflect more and such, and we learn more } \\
\text { about those things. }\end{array}$ & $\begin{array}{l}\text { Discussion, En- } \\
\text { richment, Joy of } \\
\text { learning }\end{array}$ & $\begin{array}{l}\text { The student mention } \\
\text { discussion and reflec- } \\
\text { tions as positive for } \\
\text { learning. They say that } \\
\text { it's fun and they like to } \\
\text { move past what the book } \\
\text { says. This is in line with } \\
\text { enrichment strategies. }\end{array}$ \\
\hline
\end{tabular}

The first author coded the transcriptions in NVivo 12 Pro (QSR International), computer-assisted qualitative data analysis software (Silver \& Lewins, 2015). First, by question, with all the individual answers from each informant at the same time. This method gave a sense of similarities and differences between informants. The second author conducted a preliminary coding, resulting in the same codes as the first author. After we coded all of the questions, we reread each interview and coded again. The coding sessions resulted in 98 different codes. Step three is searching for themes. We grouped some of the codes easily, while others remained separate until we determined the broader themes. Step four is reviewing themes. All authors discussed codes and preliminary themes during a meeting. The first author then wrote summaries of each theme, examined the themes for commonalities and differences, and searched for the overarching story. 


\section{"We Want to Be Educated!"}

Table 2: Relationship between themes, subthemes and codes

\begin{tabular}{|c|c|c|c|}
\hline $\begin{array}{l}\text { OVERARCHING } \\
\text { THEME }\end{array}$ & SUBTHEME & CODES & CODES \\
\hline \multirow{15}{*}{$\begin{array}{l}\text { The Educational } \\
\text { system }\end{array}$} & \multirow{3}{*}{$\begin{array}{l}\text { Adapted } \\
\text { education }\end{array}$} & Enrichment & Extra assignments \\
\hline & & Acceleration & Challenging work \\
\hline & & Adapted education & Complicity \\
\hline & \multirow{5}{*}{ Teachers } & Competent teachers & Golden Child \\
\hline & & Teacher relation & Helping teacher \\
\hline & & Overbearing teachers & Feedback \\
\hline & & Understanding teachers & Teacher - student conference \\
\hline & & & Focus on achivement \\
\hline & \multirow{2}{*}{$\begin{array}{l}\text { School - } \\
\text { home relation }\end{array}$} & Teacher relation & School - home \\
\hline & & Family & Challenging work at home \\
\hline & Primary school & Primary school & Problems with facilitation \\
\hline & \multirow{4}{*}{ School work } & Extra assignments & Projects \\
\hline & & Group work & Writing \\
\hline & & Grade scores & Ask for help \\
\hline & & Homework & Challenging work \\
\hline \multirow{6}{*}{$\begin{array}{l}\text { The Joy of } \\
\text { Learning }\end{array}$} & \multirow{3}{*}{ How I work } & Notes & Skip it \\
\hline & & Organizing & Don't want to \\
\hline & & Reading & \\
\hline & Joy of learning & Joy of learning & Motivation \\
\hline & \multirow{2}{*}{ Subjects } & Logical & Challenging work \\
\hline & & Discussions & \\
\hline \multirow{9}{*}{$\begin{array}{l}\text { Problems related } \\
\text { to school and } \\
\text { learning }\end{array}$} & \multirow{2}{*}{$\begin{array}{l}\text { Classroom (social } \\
\text { environment) }\end{array}$} & $\begin{array}{l}\text { Calm working } \\
\text { environment }\end{array}$ & Bullying \\
\hline & & Class environment & "Jantelaw" (Tall poppies) \\
\hline & \multirow{4}{*}{$\begin{array}{l}\text { Problems related } \\
\text { to myself }\end{array}$} & Detached & Fear of missing out \\
\hline & & Frustrated & Tired \\
\hline & & Gives up & Issues with concentration \\
\hline & & Need to finish & Disruptive behavior \\
\hline & \multirow{3}{*}{ Instruction } & No instruction & Adapted education \\
\hline & & Boring assignments & Freedom to choose \\
\hline & & Grouping by level & Repetition \\
\hline
\end{tabular}

Inductive thematic analysis is not a linear process (Braun et al., 2019), which we also saw in our study. After the first author wrote the thematic summaries, it was clear that there was an overweight of semantic codes and few latent codes, which prompted a new look at the material. Step five is defining and naming the themes, and step six is producing the report. We reviewed, described, discussed, and, after a meeting, 
identified the themes, determining three main themes and eleven subthemes. The main themes are: the educational system, the joy of learning, and problematic issues concerning school and learning. See table 2 for the relationship between themes and subthemes.

\section{Validity and reliability}

The terms validity and reliability are contested when it comes to qualitative research. Validity, especially, has many different denotations and connotations (Creswell \& Miller, 2000; Hammersley, 2007). Even though the terms have different value and content in qualitative research compared to quantitative research, it is still crucial for the qualitative researcher to prove the credibility and quality of the research. Inclusion criteria were nomination by a teacher or parent and a score of $95^{\text {th }}$ percentile or above on WISC-IV. WISC-IV is a cognitive measurement with an average reliability score of .97 on the full scale, and .94 on VC and .92 on PR in the original version (Wechsler, 2003). In the Norwegian translation, the $r$ score is .98 on VC, .92 on PR and .97 on full scale (Wechsler, 2009). In terms of validity, WISC-IV is an established tool for measuring cognitive ability, and it is a validated test for measuring intellectual giftedness. In the validation of WISC-IV, they tested it on a clinical group with intellectual giftedness. They found that the gifted group scored substantially higher on VC and PR but moderately higher on WM and PS (Wechsler, 2003).

We have established the validity of the thematic results in this study by several means. All three authors read the transcriptions, and then discussed and agreed on the codes and themes. We achieved data saturation (Bryant, 2015; Fusch \& Ness, 2015) in the coding around interview fourteen. No new codes emerged from the last three interviews. The first author returned to the material to look for disconfirming evidence (Creswell \& Miller, 2000). We performed member checking by inviting the participants to a session to present the themes and findings. The participants who joined this session agree that the themes represent their experiences. The tables included in the article also provide transparency.

\section{Ethics}

Norwegian Centre for Research Data has approved this study. All informants and parents gave their informed written consent (Traianou, 2015). To preserve the privacy of the participants, we have removed all names and places. We informed the participants that they could withdraw, even after the interviews. Children as participants are considered more vulnerable and need further protection than adult participants (Traianou, 2015). We have synthesized the results to create a combined story rather than sharing the individual narratives. Even so, there will be individual quotes, which emphasize essential aspects. The individual quotes are translated from Norwegian to English, which gives an extra layer of anonymity, and there are no ages, genders, or names associated with the quotes. Informants are referred to using the genderless pronoun they/them. 


\section{Findings}

Our primary research question was, "How do Norwegian gifted secondary school students experience their education?" By following Braun and Clarke's (2006) procedures for inductive thematic analysis, we developed three main themes; 1 ) the educational system, 2) the joy of learning, and 3) problematic issues concerning school and learning. The central phenomenon is that Norwegian schools' overarching system is not adequately prepared for or invested in gifted students. The informants experience that the system is not a good fit for them and that it is necessary to change policy in order to improve their educational outcomes.

\section{Theme 1: The Educational system}

The analysis shows that there are different systematic issues related to teachers, schools, adapted education, and overarching issues, such as educational law.

One of the systematic issues is teachers. Teachers can be a promotional or inhibitory factor in gifted students' education, based on their knowledge and attitudes. Our informants emphasize teachers who have helped them and teachers who have hindered their education.

I know several in my school, (...) who learn fast, (...) and they need more challenges in some subjects. And it's like they won't get it, and they are stuck with the teacher who is holding them back, and just repeat a lot they already know, and they lose motivation for the subjects.

The quote above illustrates how teachers can be an inhibitory factor if they do not differentiate the education provided. Further analysis reveals that teachers who have difficulties with classroom management, resulting in a lot of noise and disruption, may also inhibit gifted students' development.

Well, one of them, (...) it's like a lot of noise and foolishness in his classes. It's like he has no control over his students. (...) [A]Il the students they just walk around somewhere and do the complete opposite of what they are supposed to do.

The student emphasizes that a good learning environment is built on the teacher's control and classroom management skills.

Moreover, the analysis shows what kind of teachers these students prefer professional teachers who are knowledgeable in their subject and know how to convey their knowledge.

They are teachers who are very flexible and who know their subject well. And teachers who (...) manage to facilitate for everyone, for all types of students.

The quote above demonstrates that a good teacher differentiates the curriculum and adapts it to all students' needs. Further, the preferred teachers are friendly but strict 
when necessary; and the learning environment is calm and inviting. The students also describe teachers that give proper feedback.

She gives good feedback on assessments. And that's something I think is important, that you should look less on the grade itself and rather more on the assessment, like the comment on what you can do better, what was good and stuff like that, and she is very good at that.

The quote above shows that these students want more input than just a grade on paper; they want to know how to improve. A good teacher provides this kind of feedback. Furthermore, the analysis revealed other systematic issues, like a lack of communication between teachers and more of the same work instead of greater difficulty. Additionally, when the participants get challenging work, they have to work independently, as there are not enough teachers to facilitate appropriately.

I think maybe they should facilitate better. [eh] I know it's like everyone should have the same when they are at school. But I think it would have been better with more adaptation. I know it's not possible, with the way the school is now, but more adaptation for each student (...) it would be better.

In the quote above, the informant calls for more adaptation in school. It also demonstrates that when everyone gets the same input, that does not mean that the education provided is equitable. Some students say that this is probably difficult to change because that would mean changing the entire system.

[I] t's not stuff I want to change at this school, but like with the entire system, but I don't think that's realistic to think about.

These students see a fault in the system. The central issue is using groups based on the students' competence level, not just the regular age group. The participants report that splitting the age group would make it easier for the teacher to facilitate and adapt the instruction and curriculum.

[T] hey are not allowed to do that, my teacher said. Because it shouldn't be elites and such, so they are not allowed to make groups by level (...). [I]nstead, they mix people who are on a level of two or three with people who get five and six. And I don't think that works out for either of them.

Moreover, the analysis displays that grouping by level is considered elitist. According to participants, this notion makes it harder to adapt the education for all students.

The analysis in this study revealed that it seems easier to facilitate for gifted students in secondary school. Primary school (especially 1-4) appears to be the most disruptive and tedious for these students, and they talk about acceleration in an unfavorable view. 
In primary school, there was a lot less adaptation compared to secondary school. Like, (...) I work with 10th-grade math now, and I have a teacher teaching me. But in primary school, I just sat in the classroom with headphones on and did my own thing; there was no teaching.

The quote above reflects both the difference between primary and secondary school and the systematic issue with facilitation.

Besides, the analysis demonstrates that schoolwork is a systematic issue. These students share the same experience with group work; they get stuck with all the work and must carry the entire group.

[B]ut I don't like cooperative work. (...) Why not? Because (...), especially if you have projects and such, (...) you get placed in a group where it's quite different how motivated you are. So you get stuck with a lot of work, and I don't like that. It's very annoying, (...) Since I want the entire project to be good, not just my part, even if it's an individual grade in the project, it's like I want it to be perfect, so then I get stuck with a lot of work and do everything myself.

The quote above also illustrates another vital aspect, which is involvement and participation. In the Norwegian educational law (The Education Act, 1998, §1-1), the students have the right to be involved and affect their education. On the whole, the informants regarded participation as occurring through the student council, and not as a way of influencing their education.

\section{Theme 2: The Joy of Learning}

The analysis revealed different ways of learning in school. The informants enjoyed learning new things, especially logical subjects, and more significant projects that combined various subjects and art elements.

In the analysis of how these students learn best, there are individual differences and shared experiences. Some of the students mention taking notes and organizing their learning, while others feel that notes are disturbing and they learn more by focusing on the teacher or reading.

[A]nd I think it's fun just to find out things like just go on Wikipedia and read about German minorities in Slovenia; I think that's interesting. Just learning and learning. That's fun!

The above extract displays the joy of learning these students have. The students talk with enthusiasm about the subjects they enjoy. They speak about logical subjects like math or science in optimistic terms. These subjects are rational and easily understandable, and they appreciate using this part of their brain. In addition, the participants consider discussions as fruitful for learning and questions that make you reflect as rewarding. 
The analysis clarifies that project assignments, where they need to develop their own research question, are valid methods for learning and getting more challenges.

For example, when we in science were supposed to make this health booklet, and that was fun because I didn't know much about it; at the same time, you got to mix in knowledge from the book with graphic design and art.

The quote above demonstrates that project work can encompass different subjects and include art, which these students seem to enjoy.

\section{Theme 3: Problematic issues concerning school and learning}

The analysis revealed that each informant mentions problematic issues related to their education. There are different aspects of their experience in school that disturb their learning.

The analysis displays that other students in school might disrupt education and learning.

[T]here was a lot of noise and disruption, and we didn't do anything, the teacher didn't know what I was supposed to do, so I just sat there and did nothing and got really frustrated. I was really mad at everything and everyone actually, since none of them were listening, and there was so much noise.

The above extract illustrates how frustrated these students can get when someone disturbs their learning and education. The informants also need less repetition, varied instruction, more freedom to choose, facilitated education, and grouping by levels. When they do not get this kind of differentiation, they get bored and frustrated.

Repetition is, really, I think it's just a waste of time for me when I know I could have used that time to learn something new, instead of repeating what we had two days ago.

One student calls for a proper education, not just being expected to learn on their own.

I don't like the way (...) they teach me in math. Or it's not even teaching, the way they want me to learn math on my own. I can't sit in a room with a book and learn like that. You want to be taught? I want to be educated! But not instructed how to calculate the volume of a dice; (...) that's just boring.

The two quotes above emphasize the need for proper adaptation and facilitation in school. The informants are frustrated by repetition or sitting by themselves and learning independently. They want a proper education, not self-study. 
The analysis further demonstrates that when the informants get bored and frustrated in school, they display disruptive behavior. This disruptiveness can take the form of daydreaming (being detached from the learning situation or task at hand) or physical disruptions (talking, walking, etc.).

Mhm, and I used to talk a lot in class. They said I had to be quieter and not disturb others. If you think back to that time, do you remember why you

were talking in class? It was because it was boring, so I talked to people.

Boredom also leads to issues with concentration and feelings of fatigue. The students report how challenging it is to concentrate and put effort into tedious and unnecessary assignments. They do not put the same effort into these kinds of tasks as they would more challenging tasks. Moreover, the analysis revealed other problematic issues like perfectionism, that they need to stay on top of everything and are afraid of missing out on their education.

To sum up, the students want teachers who are competent and can adapt the education to their needs. The informants report that their education is better adapted in secondary school. There are issues related to the educational system, which indicate that the system is not optimal for them. Further, the informants reflect on how they learn best, and that they like project assignments, reflection, and discussions. Repetition and unnecessary work and assignments are tedious and result in a lack of concentration and disruptive behavior.

\section{Discussion \\ Equitable education}

Every student in Norwegian primary, secondary, and upper secondary school has the right to an inclusive, equitable education adapted to their needs and abilities (The Education Act, 1998, § 1-1, § 1-3). This study indicates systematic challenges that might lead to education without equity, inclusion, and adaptation.

The results in theme 1 reveal that the students want more grouping based on level. In Norway, the educational law emphasizes that you cannot regularly split student groups by competence level (The Education Act, 1998, § 8-2). The law does not permit schools and teachers to make permanent groups based on level, except for students with special education needs. However, it is allowed if such a grouping is less regular. Teachers might not be aware of this exception. In the official report from 2016 (NOU 2016:14, 2016), the authors mention grouping by level as a missed opportunity. Gifted students benefit from special groups and grouping within the class or across grades (Steenbergen-Hu et al., 2016). Individualization and differentiation are core principles in gifted education, but this is not easy to achieve in same age groups, which are heterogeneous in development and learning needs (Mönks \& Katzko, 2005). The NOU (2016) argues that both teachers and schools might be underutilizing this option. Our results indicate the same. 
Teachers are essential in the DMGT and the MMG (Gagné, 2010; Mönks \& Katzko, 2005). Teachers must be aware of the needs of the student and how to facilitate them properly. One result in theme 1 displays that a good teacher facilitates these students. These findings are on par with other qualitative studies that find that students value teacher competence and teacher personality, novelty, and creativity (Gomez-Arizaga et al., 2020; Samardzija \& Peterson, 2015). In the DMGT, the chance element is a catalyst that affects both the developmental process and the environmental and intrapersonal catalyst (Gagné, 2004, 2010). As we see in the results, there are different experiences between the different students regarding the provisions and adaptation they receive, indicating that getting a teacher who provides and facilitates them influences how they experience their education. As in Schmitt and Goebel's (2015) study, teachers might promote or hinder gifted students' development. The educational system should reduce the amount of chance and how chance affects the education of gifted students.

Wendelborg and Caspersen (2016) show that high achievers receive less support and fewer challenges than their peers. Smedsrud (2018) found that gifted students did not receive sufficient challenges, especially in primary school; Persson (2010) shows similar results from Sweden. In our study, the students are more pleased with their experience in secondary school and say the education there is better adapted. It is difficult to speculate on why there is a difference; it might be primary teachers' competence or knowledge about giftedness and gifted students' needs. It might be, as in Sweden, that the increased difficulty in secondary school makes it easier to differentiate or that specialized subject teachers find it easier to enrich the curriculum (Persson, 2010). The results further demonstrate that the facilitation and adaptation for these students does not provide them with enough opportunities to develop their potential. Equitable education does not mean education that is the same for everyone - equity in education requires differentiation (Nordahl et al., 2018).

\section{Educational provisions}

Education for gifted students can be adapted by utilizing content from a higher grade level and assignments that foster critical thinking and problem solving (Betts, 2004; VanTassel-Baska \& Hubbard, 2016). Provisions like adaptation and facilitation are an essential part of the DMGT and the MMG (Gagné, 2010; Mönks \& Katzko, 2005). Adaptation through ordinary education might not necessarily fulfill the needs of gifted students. The individual right to adaptation in special education might give gifted students greater opportunity to utilize their potential. However, the Norwegian educational authority does not acknowledge giftedness as a "special" education need (NDET, 2014, p. 13). Are we losing some potential by neglecting that giftedness might be a "special" education need?

One of the provisions we see in the result is acceleration. Some participants have skipped a year, while others attend an accelerated subject. Acceleration is a tried and valued type of facilitation as it provides the necessary speed and less repetition (Sayler \& Brookshire, 1993). Acceleration might mean starting school at five instead of six 
(The Education Act, 1998, § 2-1), skipping a grade, or subject acceleration. The most significant problem we found with subject acceleration is getting it to work; you need the entire school environment to work together. There might also be issues related to the myth about the harmful effects of acceleration, but acceleration does not negatively affect students socially or psychologically, and acceleration has a positive and significant effect on academic achievement (Bernstein et al., 2020; Steenbergen-Hu et al., 2016). Schools need to develop a system that makes it easier for students to take accelerated subjects (NOU 2016: 14, 2016). An overarching system would also reduce the chance element in what kind of provisions gifted students get.

In theme 2, the analysis revealed how the participants feel they learn best. Logical subjects, reflection, discussion, project assignments, and creative and practical assignments are fruitful for their learning. These results are similar to previous research that mentions discussion (Brandišauskienè 2019), logical subjects like math and science (McGrath 2019; Mujtaba \& Reiss, 2016), reflection (Borovay et al. 2019), and creative enrichment projects (Brigandi et al., 2016; Gomez-Arizaga et al., 2020). Teachers need to know how to adapt the education so gifted students can utilize their potential. The forms of adaptation mentioned here are inclusive (Rasmussen \& Lindgård, 2018) and possible to utilize in ordinary adapted education. When a teacher evaluates a gifted student's education, they should ask that student how they learn best and what motivates them, and use this information when adapting the education. A gifted student might need differentiation both in terms of types of assignments and content.

The results in theme 3 show how problematic issues can lead to frustration and boredom. The examination further showed that when gifted students get bored and frustrated, they turn to disruptive behavior. Some research points to the relationship between giftedness and behavioral problems (Bakar \& Ishak, 2014; Kennedy, 2002; Saunders, 2003; Shaywitz et al., 2001). Others find that gifted students show fewer behavioral issues (Cornell et al., 1994; Francis et al., 2015; Sayler \& Brookshire, 1993; Shechtman \& Silektor, 2012). It seems that gifted students in gifted programs are less likely to show behavioral issues like disruptive behavior. But, the picture is different for gifted students who lack adaptation. There are no gifted programs per se in Norway, and students with high learning potential are reliant on their teachers and the provisions provided by their school.

\section{Limitations}

Qualitative researchers need to be aware of and reflect on the inherent biases and assumptions we bring to research (Becker, 1967; Finlay \& Gough, 2003). Becker (1967) argues that sociological research should inform the reader about which side the research favors. This study focuses on students' perspectives, and teachers might disagree with this presentation. The themes are a product of how we analyzed the interviews and are subject to our biases. Themes do not emerge from the data, we are not discovering diamonds (Braun \& Clarke, 2016; Constas, 1992), and different researchers might produce different themes. 
As this is an inductive qualitative study with only seventeen participants, it is impossible to generalize the findings to all gifted students in Norway. There were some differences in interview duration, with the shortest interview at sixteen minutes. This participant answered every question but was much less talkative than the other participants.

\section{Conclusion}

Previous research on gifted students in Norway is scarce, and this study contributes to this area of research with valuable knowledge about how gifted students experience their education in primary and secondary school. The study's themes reveal that the informants' experience of their education is that it is not adequately adapted to their needs and abilities. The students experience different issues that affect and disturb their learning in school, including issues with the system, with a particular teacher or classroom, or how they handle boring assignments. According to the DMGT and MMG (Gagné, 2010; Mönks \& Katzko, 2005), teachers and schools are necessary for developing gifts to talents. Our results indicate that the Norwegian educational system is not adequately prepared to give gifted students the conditions they need to further their development. This means that each teacher must provide students with the necessary facilitation. Still, the teacher might have limited knowledge about giftedness and adaptation for gifted students. It highlights the chance element in DMGT and how this affects the education of gifted students. Systematic challenges concerning acceleration and adaption need to be addressed so that gifted students in Norway can receive an inclusive, equitable and adapted education.

\section{Implications and further research}

Our study is important for teachers as we highlight gifted students' experiences in Norway and their needs. Our results are also valuable for policymakers. It might be necessary to implement changes on a systemic level to better provide for gifted students and reduce the chance element in their education. There is a need for more knowledge and information about gifted students in Norwegian teacher education and for policymakers.

Further research should investigate how to facilitate these students, as well as how to explore teachers' perspectives. Exploring giftedness and disruptive behavior in Norwegian schools is also of interest. How prevalent disruptive behavior is in the Norwegian gifted student population is impossible to say based on this study.

\section{REFERENCES}

Bakar, A. B. Y. \& Ishak, N. M. (2014). Depression, anxiety, stress, and adjustments among Malaysian gifted learners: Implication towards school counseling provision. International Education Studies, 7(13), 6-13. http://dx.doi.org/10.5539/ies.v7n13p6 
Becker, H. S. (1967). Whose side are we on? Social Problems, 14(3), 239-47. https://doi. org/10.2307/799147

Bernstein, B. O., Lubinski, D. \& Benbow, C. P. (2020). Academic acceleration in gifted youth and fruitless concerns regarding psychological well-being: A 35-year longitudinal study. Journal of Educational Psychology. https://doi.org/10.1037/edu0000500

Betts, G. (2004). Fostering autonomous learners through levels of differentiation. Roeper Review, 26(4), 190-191. https://doi.org/10.1080/02783190409554269

Borovay, L. A., Shore, B. M., Caccese, C., Yang, E. \& Hua, O. L. (2019). Flow, achievement level, and inquiry-based learning. Journal of Advanced Academics, 30(1), 74-106. https://doi. org/10.1177/1932202X18809659

Børte, K., Lillejord, S. \& Johansson, L. (2016). Evnerike elever og elever med stort laringspotensial: En forskningsoppsummering [Gifted students and students with high learning potential: A research summary]. Kunnskapssenter for utdanning. https://www.forskningsradet.no/ siteassets/publikasjoner/1254019980213.pdf

Brandišauskienè, A. (2019). "I am more than my IQ": Analysis of the experience of a gifted learner. Gifted Education International, 35(3), 201-215. https://doi.org/10.1177/0261429 419840648

Braun, V. \& Clarke, V. (2006). Using thematic analysis in psychology. Qualitative Research in Psychology, 3(2), 77-101. https://www.tandfonline.com/doi/abs/10.1191/1478088706qpo630a

Braun, V. \& Clarke, V. (2016). (Mis)conceptualising themes, thematic analysis, and other problems with Fugard and Potts' (2015) sample-size tool for thematic analysis. International Journal of Social Research Methodology, 19(6), 739-43. https://doi.org/10.1080/13645579.2016.1195588

Braun, V., Clarke, V., Hayfield, N. \& Terry, G. (2019). Thematic analysis. In P. Liamputtong (Ed.), Handbook of research methods in health social sciences (pp. 843-60). Springer.

Braun, V., Clarke, V. \& Rance, N. (2015). How to use thematic analysis with interview data. In A. Vossler \& N. Moller (Eds.), The counselling and psychotherapy research handbook (pp. 183-197). Sage Publications.

Brigandi, C. B., Siegle, D., Weiner, J. M., Gubbins, E. J. \& Little, C. A. (2016). Gifted secondary school students: The perceived relationship between enrichment and goal valuation. Journal for the Education of the Gifted, 39(4), 263-287. https://doi.org/10.1177/0162353216671837

Brinkmann, S. (2015). Unstructured and semi-structured interviewing. In P. Leavy (Ed.), The Oxford handbook of qualitative research (pp. 277-299). Oxford University Press.

Bryant, A. (2015). The grounded theory method. In P. Leavy (Ed.), The Oxford handbook of qualitative research (pp. 116-136). Oxford University Press.

Constas, M. A. (1992). Qualitative analysis as a public event: The documentation of category development procedures. American Educational Research Journal, 29(2), 253-266. https://doi. org/10.3102/00028312029002253

Cornell, D. G., Delcourt, M. A., Bland, L. C., Goldberg, M. D. \& Oram, G. (1994). Low incidence of behavior problems among elementary school students in gifted programs. Journal for the Education of the Gifted, 18(1), 4-19. https://doi.org/10.1177/016235329401800102

Creswell, J. W. \& Miller, D. L. (2000). Determining validity in qualitative inquiry. Theory Into Practice, 39(3), 124-130. https://www.jstor.org/stable/1477543

Cross, J. R. \& Cross, T. L. (2015). Clinical and mental health issues in counseling the gifted individual. Journal of Counseling and Development, 93(2), 163-172. https://doi.org/10.1002/ j.1556-6676.2015.00192.x

Cross, T. L., Coleman, L. J. \& Terhaar-Yonkers, M. (2014). The social cognition of gifted adolescents in schools: Managing the stigma of giftedness. Journal for the Education of the Gifted, 37(1), 30-39. https://doi.org/10.1177/0162353214521492 
Dare, L. \& Nowicki, E. (2019). Beliefs about educational acceleration: Students in inclusive classes conceptualize benefits, feelings, and barriers. The Journal of Educational Research, 112(1), 86-97. https://doi.org/10.1080/00220671.2018.1440368

Dodillet, S. (2019). Inclusive elite education in Sweden: Insights from implementing excellence programs into an egalitarian school culture. Scandinavian Journal of Educational Research, 63(2), 258-271. https://doi.org/10.1080/00313831.2017.1336480

Finlay, L. \& Gough, B. (Eds.). (2003). Reflexivity: A practical guide for researchers in health and social sciences. Blackwell Science.

Francis, R., Hawes D. J. \& Abbott, M. (2015). Intellectual giftedness and psychopathology in children and adolescents: A systematic literature review. Exceptional Children, 82(3), 279302. https://doi.org/10.1177/0014402915598779

Frantz, R. S. \& McClarty, K. L. (2016). Gifted education's reflection of country-specific cultural, political, and economic features. Gifted and Talented International, 31(1), 46-58. https://doi. org/10.1080/15332276.2016.1220794

Fusch, Patricia I. \& Lawrence R. Ness. (2015). Are we there yet? Data saturation in qualitative research. The Qualitative Report; Fort Lauderdale, 2o(9), 1408-1416. https://search.proquest. com/docview/1721368991?accountid=8579

Gagné, F. (1995). From giftedness to talent: A developmental model and its impact on the language of the field. Roeper Review, 18(2), 103-111. https://doi.org/10.1080/027831995 09553709

Gagné, F. (2004). Transforming gifts into talents: The DMGT as a developmental theory. High Ability Studies, 15(2), 119-147. https://doi.org/10.1080/1359813042000314682

Gagné, F. (2010). Motivation within the DMGT 2.0 framework. High Ability Studies, 21(2), 81-99. https://doi.org/10.1080/13598139.2010.525341

Geake, J. G. \& Gross, M. U. M. (2008). Teachers' negative affect toward academically gifted students: An evolutionary psychological study. Gifted Child Quarterly, 52(3), 217-231. https:// doi.org/10.1177/0016986208319704

Gomez-Arizaga, M. P., Valdivia-Lefort, M., Castillo-Hermosilla, H., Hébert T. P. \& Conejeros-Solar, M. L. (2020). Tales from within: Gifted students' lived experiences with teaching practices in regular classrooms. Education Sciences, 10(5), 137. https://doi.org/10.3390/educsci10050137

Gorard, S. (2001). Quantitative methods in educational research: The role of numbers made easy. Continuum.

Hammersley, M. (2007). The issue of quality in qualitative research. International Journal of Research \& Method in Education, 30(3), 287-305. https://doi.org/10.1080/17437270701614782

Kennedy, D. M (2002). Glimpses of a highly gifted child in a heterogeneous classroom. Roeper Review, 24(3), 120-124. https://doi.org/10.1080/02783190209554148

Kvale, S. \& Brinkmann, S. (2015). Det kvalitative forskningsintervju. Gyldendal Akademisk. McGrath, P. (2019). Education in Northern Ireland: Does it meet the needs of gifted students? Gifted Education International, 35(1), 37-55. https://doi.org/10.1177/0261429418784165

Ministry of Children and Families. (1991). FNs konvensjon om barnets rettigheter [UN convention on the right of the child]. Barne- og familiedepartementet. https://www.regjeringen.no/ globalassets/upload/kilde/bfd/bro/2004/0004/ddd/pdfv/178931-fns_barnekonvensjon.pdf

Mujtaba, T. \& Reiss, M. J. (2016). "I fall asleep in class ... but physics is fascinating": The use of large-scale longitudinal data to explore the educational experiences of aspiring girls in mathematics and physics. Canadian Journal of Science, Mathematics and Technology Education, 16(4), 313-330. https://doi.org/10.1080/14926156.2016.1235743

Mönks, F. J. \& Pflüger, R. (2005). Gifted education in 21 European countries: Inventory and perspective. Radboud University Nijmegen. https://www.giftedforyou.eu/plovdiv-guide/17.pdf 
Mönks, F. J. \& Katzko, M. W. (2005). Giftedness and gifted education. In R. J. Sternberg \& J. E. Davidson (Eds.), Conceptions of giftedness (2nd ed.). Cambridge University Press.

Nordahl, T. et al. (2018). Inkluderende fellesskap for barn og unge. Ekspertgruppen for barn og unge med behov for scerskilt tilretttelegging [Including community for children and youth. The expert group for children and youth with need for special adaption]. https://nettsteder. regjeringen.no/inkludering-barn-unge/files/2018/04/INKLUDERENDE-FELLESSKAP-FORBARN-OG-UNGE-til-publisering-04.04.18.pdf

NOU 2016: 14 (2016). Mer å hente. Bedre laring for elever med stort laringspotensial [More to gain. Better learning for students with high learning potential]. Kunnskapsdepartementet. https://www.regjeringen.no/no/dokumenter/nou-2016-14/id2511246/

Parliamentary Assembly Council of Europe. (1994). Doc 7140. Report on education for gifted children. https://assembly.coe.int/nw/xml/XRef/X2H-Xref-ViewHTML.asp?FileID= 8142\&lang=EN

Persson, R. S. (2010). Experiences of intellectually gifted students in an egalitarian and inclusive educational system: A survey study. Journal for the Education of the Gifted, 33(4), 536-569. https://doi.org/10.1177/016235321003300405

Peterson, J. S. (2009). Myth 17: Gifted and talented individuals do not have unique social and emotional needs. Gifted Child Quarterly, 53(4), 280-282. https://doi.org/10.1177/001698 6209346946

Rasmussen, A. \& Lingard, B. (2018). Excellence in education policies: Catering to the needs of gifted and talented or those of self-interest? European Educational Research Journal. https:// doi.org/10.1177/1474904118771466

Reid, E. \& Boettger, H. (2015). Gifted education in various countries of Europe. Slavonic Pedagogical Studies Journal, 4(2), 158-171. https://doi.org/10.18355/PG.2015.4.2.158-171

Renzulli, J. S. (2012). Reexamining the role of gifted education and talent development for the 21st century. Gifted Child Quarterly, 56(3), 150-159. https://doi.org/10.1177/001698 6212444901

Samardzija, N. \& Peterson, J. S. (2015). Learning and classroom preferences of gifted eighth graders: A qualitative study. Journal for the Education of the Gifted, 38(3), 233-256. https:// doi.org/10.1177/0162353215592498

Saunders, C. L. (2003). Case study: A gifted child at risk. Journal of Secondary Gifted Education, 14(2), 100-106. https://journals.sagepub.com/doi/pdf/10.4219/jsge-2003-417

Sayler, M. F. \& Brookshire, W. K. (1993). Social, emotional, and behavioral adjustment of accelarated students, students in gifted classes, and regular students in eighth grade. Gifted Child Quarterly, 37(4), 150-154. https://journals.sagepub.com/doi/ pdf/10.1177/001698629303700403

Shaywitz, S. E., Holahan J. H., Freudenheim, D. A., Fletcher, J. M., Makuch, R. W. \& Shaywitz, B. A. (2001). Heterogeneity within the gifted: Higher IQ boys exhibit behaviors resembling boys with learning disabilities. Gifted Child Quarterly, 45(1), 16-23. https://doi.org/10.1177/ 001698620104500103

Shechtman, Z. \& Silektor, A. (2012). Social competencies and difficulties of gifted children compared to nongifted peers. Roeper Review, 34(1), 63-72. https://doi.org/10.1080/02783193. 2012.627555

Silver, C. \& Lewins, A. F. (2015) Computer-assisted analysis of qualitative research. In P. Leavy (Ed.), The Oxford handbook of qualitative research (pp. 606-638). Oxford University Press.

Smedsrud, J. (2018). Mathematically gifted accelerated students participating in an ability group: A qualitative interview study. Frontiers in Psychology, 9, 1359. https://doi.org/10.3389/ fpsyg.2018.01359 
Smith, C. \& Goebel, V. (2015). Experiences of high-ability high school students: A case study. Journal for the Education of the Gifted, 38(4), 428-446. https://doi.org/10.1177/0162353 215607325

Steenbergen-Hu, S., Makel, M. C. \& Olszewski-Kubilius, P. (2016). What one hundred years of research says about the effects of ability grouping and acceleration on $\mathrm{K}-12$ students' academic achievement: Findings of two second-order meta-analyses. Review of Educational Research, 86(4), 849-899. https://doi.org/10.3102/0034654316675417

Subotnik, R. F., Olszewski-Kubilius, P. \& Worrell, F. C. (2011). Rethinking giftedness and gifted education: A proposed direction forward based on psychological science. Psychological Science in the Public Interest, 12(1), 3-54. https://doi.org/10.1177/1529100611418056

The Education Act. (1998). Lov om grunnskolen og den vidaregåande opplæringa (LOV-199807-17-61). https://lovdata.no/dokument/NL/lov/1998-07-17-61

The Norwegian Directorate for Education and Training. (2014). Veilederen spesialundervisning [Guidance for special education]. https://www.udir.no/laring-og-trivsel/sarskilte-behov/ spesialundervisning/Spesialundervisning/

The Norwegian Directorate for Education and Training. (2020). Tilpasset opplaring [Adapted education]. https://www.udir.no/laring-og-trivsel/tilpasset-opplaring/

Tirri, K. \& Kuusisto, E. (2013). How Finland serves gifted and talented pupils. Journal for the Education of the Gifted, 36(1), 84-96. https://doi.org/10.1177/0162353212468066

Traianou, A. (2015). The centrality of ethics in qualitative research. In P. Leavy (Ed.), The Oxford handbook of qualitative research (pp. 62-77). Oxford University Press.

UNESCO. (1994). The Salamanca statement and sframework for action on special needs education. United Nations Educational, Scientific and Cultural Organization. https://www.right-toeducation.org/sites/right-to-education.org/files/resource-attachments/Salamanca_ Statement_1994.pdf

VanTassel-Baska, J. \& Hubbard, G. F. (2016). Classroom-based strategies for advanced learners in rural settings. Journal of Advanced Academics, 27(4), 285-310. https://doi. org/10.1177/1932202X16657645

Wechsler, D. (2003). WISC-IV technical and interpretive manual. Pearson Assessment.

Wechsler, D. (2009). WISC-IV norsk versjon manual del 1. (Heldal, L. \& Haukeland, E., Trans). Pearson Assessment.

Wendelborg, C. \& Caspersen, J. (2016). Høyt presterende elevers vurdering av laringsmiljøet. NTNU Samfunnsforskning AS. https://samforsk.no/Publikasjoner/2016/H\%C3\%B8yt\%20 presterende\%20elever\%20WEB.pdf

Yavuz, E., Mehmet, S., Birben Fazilet, Y. \& Hatun, S. Y. (2016). Motivation levels of gifted students and their metaphorical perceptions of school. Educational Research and Reviews, 11(8), 553-61. https://doi.org/10.5897/ERR2016.2697 